\title{
PENGARUH PEMBERIAN KOMPRES HANGAT PADA LEHER UNTUK MENGURANGI NYERI DI KEPALA PADAPASIEN HIPERTENSI
}

\section{Arfah May Syara ${ }^{1 *}$, Tiurma Siringoringo ${ }^{1}$, Afeus Halawa ${ }^{1}$, Kristina Sitorus ${ }^{1}$}

${ }^{1}$ Program Studi Keperawatan Program Sarjana, Institut Kesehatan Medistra Lubuk Pakam

\author{
JIn. Sudirman No.38 Lubuk Pakam, Kabupaten Deli Serdang, \\ Sumatera Utara - Indonesia \\ *email korespondensi author: amaysyara@gmail.com
}

DOI 10.35451/jpk.v1i1.756

\begin{abstract}
Abstrak
Peningkatan abnormal tekanan darah di arteri, atau peningkatan tekanan darah sistolik lebih dari $140 \mathrm{mmHg}$ dan tekanan darah diastolik lebih dari $90 \mathrm{mmHg}$ dalam dua pembacaan dengan interval lima menit dalam keadaan cukup tenang/istirahat, diketahui seperti hipertensi atau tekanan darah tinggi. Sakit leher adalah salah satu indikasi dan gejala hipertensi (nyeri leher) yang paling umum. Kebutuhan kenyamanan pasien hipertensi tidak terpenuhi karena nyeri leher akibat hipertensi. Kompres hangat merupakan salah satu cara nonfarmakologis yang dapat digunakan perawat di rumah sakit karena tidak menimbulkan risiko bagi pasien dan mudah dilakukan. Terapi komplementer bersifat pengobatan alami untuk menangani penyebab penyakit dan memacu tubuh sendiri untuk menyembuhkan penyakitnya. Kompres hangat adalah pemberian rasa hangat/panas didaerah tertentu. skala nyeri pada leher pada pasien hipertensi sebelum dilakukan terapi kompres hangat, dikatakan nyeri sedang 4 orang responden (28,6\%), nyeri berat 10 orang responden $(71,4 \%)$ dengan standar deviasi 0,469. Skala nyeri pasien hipertensi sesudah dilakukan terapi kompres hangat, dikatakan sedang 12 orang responden (85.7\%), berat 2 orang responden (14.3\%) dengan standar deviasi 0.426. Pasien hipertensi yang mengalami nyeri leher berat mengalami penurunan, sebelum diberikan perlakuan sebanyak 10 orang, setelah diberikan perlakuan sebanyak 2 orang. Penerapan untuk kompres hangat pada pasien hipertensi terus dilakukan untuk terapi non farmakologi yang dapat dilakukan oleh masyarakat di rumah.
\end{abstract}

Kata kunci: Hipertensi, Nyeri, Kompres Hangat

\begin{abstract}
An abnormal increase in arterial blood pressure, or an increase in systolic blood pressure of more than $140 \mathrm{mmHg}$ and a diastolic blood pressure of more than 90 $\mathrm{mmHg}$ in two readings at five-minute intervals in a moderately calm/resting state, is known as hypertension or high blood pressure Neck pain is one of the most common indications and symptoms of hypertension (neck pain). The comfort needs of hypertensive patients are not met because of neck pain due to hypertension. Warm compresses are one of the non-pharmacological methods that nurses can use in hospitals because they do not pose a risk to patients and are easy to do. Complementary therapy is a natural treatment to treat the cause of the disease and spur the body itself to heal the disease. Warm compresses are giving a feeling of warmth / heat in certain areas. neck pain scale in hypertensive patients before warm compress therapy, said moderate pain 4 respondents $(28.6 \%)$, severe pain 10 respondents $(71.4 \%)$ with a standard deviation of 0.469 . The pain scale of hypertensive patients after warm compress therapy was said to be moderate for 12 respondents $(85.7 \%)$, the weight of 2 respondents (14.3\%) with a standard deviation of 0.426. Hypertensive patients who experienced severe neck pain decreased, before being given treatment as many as 10 people, after being given treatment as many as
\end{abstract}


Received: 17 June 2021 :: Accepted: 22 June 2021 :: Published: 30 June 2021

2 people. The application of warm compresses to hypertensive patients continues to be carried out for non-pharmacological therapy that can be carried out by the community at home.

Keywords: Hypertension, Pain, Warm compress.

\section{Pendahuluan}

Tekanan darah tinggi yang sering disebut dengan hipertensi merupakan penyakit yang menyerang masyarakat baik di negara industri maupun negara berkembang, termasuk Indonesia. Meskipun hipertensi adalah pembunuh diam-diam, itu tidak diakui secara luas sebagai penyakit mematikan karena hipertensi ditemukan selama pemeriksaan rutin atau ketika pasien datang dengan masalah lain (Setyawan, 2014).

Salah satu penyebab kematian terbesar di dunia adalah hipertensi. Hipertensi akan mempengaruhi sekitar 1,56 miliar orang pada tahun 2020. Hipertensi membunuh sekitar 8 miliar orang di seluruh dunia setiap tahun, termasuk hampir 1,5 juta orang di Asia Timur-Selatan.

Hipertensi mempengaruhi sekitar sepertiga orang di Asia Tenggara (World Health Organization, 2015).

Hipertensi lebih sering terjadi sebagai akibat dari perubahan gaya hidup seperti merokok, obesitas, aktivitas fisik, dan stres psikologis. Hipertensi telah menjadi masalah kesehatan masyarakat, dan jika tidak ditangani sejak dini akan semakin parah. Bahkan di negara-negara kaya, pengendalian hipertensi tidak cukup (Kemenkes RI, 2015).

Berdasarkan data dari Riskesdas Litbang Depkes (2015), hipertensi di Indonesia merupakan masalah kesehatan dengan prevalensi yang tinggi yaitu sebesar 25,8\%. Prevalensi tertinggi di Bangka Belitung 30,9\%. diikuti kalimantan Selatan 30,8\%. Kalimantan Timur 29,6\%. Jawa Barat $29,4 \%$ dan Gorontalo 29,4\%. Indonesia telah melakukan beberapa cara untuk mengingatkan masyarakat tentang bahaya hipertensi, komplikasinya, dan cara penanganannya (Kemenkes RI, 2014).
Terapi nonfarmakologis adalah jenis pengobatan yang tidak termasuk penggunaan obat-obatan dan tidak memiliki efek samping negatif, seperti mengikuti diet, menurunkan berat badan, berolahraga secara teratur, menghindari alkohol, menggunakan kompres hangat, dan menghindari stres. Kompres hangat merupakan salah satu cara nonfarmakologis yang dapat digunakan perawat di rumah sakit karena tidak menimbulkan risiko bagi pasien dan mudah dilakukan. Terapi herbal, relaksasi, latihan pernapasan, meditasi, dan terapi musik adalah contoh terapi komplementer. Terapi komplementer adalah pengobatan alami untuk mengatasi penyakit dan mendorong tubuh untuk menyembuhkan dirinya sendiri, sedangkan pengobatan adalah pengobatan untuk meringankan gejala kondisi (Vitahealth, 2014).

\section{Metode}

Kegiatan Pengabdian Kepada Masyarakat (PKM) ini menggunakan metode berupa sosialisasi penyuluhan kesehatan terkait dengan pemberian kompres hangat di leher pada pasien hipertensi. Dengan tujuan mengurangi nyeri kepala pada pasien hipertensi Kegiatan PKM ini dilakukan di Rumah Sakit Grandmed Lubuk Pakam. Sasaran pada kegiatan PKM ini adalah pasien hipertensi yang mengalami sakit kepala yang berjumlah 14 orang. Pada pengabdian ini pasien dengan hipertensi diberikan penyuluhan tentang kompres hangat di leher, dan diajarkan cara melakukan kompres hangat yang diberikan kepada pasien hipertensi. 
Received: 17 June 2021 :: Accepted: 22 June 2021 :: Published: 30 June 2021

\section{Hasil dan Pembahasan}

\subsection{Hasil}

Tabel 1. Rata-Rata Nyeri Kepala Sebelum dilakukan Kompres Hangat

Skala Frekuensi Persentase Standar

nyeri (f) (\%) Deviasi

(SD)

\begin{tabular}{|c|c|c|c|}
\hline $\begin{array}{c}\text { Seda } \\
\text { ng } \\
\text { Berat }\end{array}$ & 10 & $\begin{array}{l}28.6 \\
71.4\end{array}$ & 0.469 \\
\hline Total & 14 & 100 & \\
\hline
\end{tabular}

analisa skala nyeri pada leher pada pasien hipertensi sebelum dilakukan terapi kompres hangat, dikatakan nyeri sedang 4 orang responden $(28,6 \%)$, nyeri berat 10 orang responden $(71,4 \%)$ dengan standar deviasi 0,469 .

Tabel 2. Rata-Rata Nyeri Kepala sesudah dilakukan Kompres Hangat

\begin{tabular}{cccc}
\hline $\begin{array}{c}\text { Skala } \\
\text { nyeri }\end{array}$ & $\begin{array}{c}\text { Frekuensi } \\
(\mathrm{N})\end{array}$ & $\begin{array}{c}\text { Persentase } \\
(\%)\end{array}$ & $\begin{array}{c}\text { Standar } \\
\text { Deviasi } \\
(\mathrm{SD})\end{array}$ \\
\hline Sedang & 12 & 85.7 & \\
Berat & 2 & 14.3 & 0.426 \\
\hline Total & 14 & 100 &
\end{tabular}

Tabel 2 menunjukkan bahwa hasil analisa skala nyeri pasien hipertensi sesudah dilakukan terapi kompres hangat, dikatakan sedang 12 orang responden $(85.7 \%)$, berat 2 orang responden $(14.3 \%)$ dengan standar deviasi 0.426 .

\subsection{Sosialisasi penyuluhan kesehatan kompres hangat}

Sosialisasi yang diberikan kepada masyarakat pada kegiatan PKM ini meliputi penyuluhan kesehatan tentang pemberian kompres hangat di leher pada pasien hipertensi. Leher dikompres dengan menggunakan buli-buli air panas selama 15 menit pada saat pasien hipertensi mengalami nyeri di kepala.

\section{Kesimpulan}

Pasien hipertensi yang mengalami nyeri leher berat mengalami penurunan, sebelum diberikan perlakuan sebanyak
10 orang, setelah diberikan perlakuan sebanyak 2 orang. Penerapan untuk kompres hangat pada pasien hipertensi terus dilakukan untuk terapi non farmakologi yang dapat dilakukan oleh masyarakat di rumah.

\section{Ucapan Terima Kasih}

Ucapan terima kasih yang sebesar-besarnya kepada Institut Kesehatan Medistra Lubuk Pakam, Lembaga Penelitian dan Pengabdian kepada Masyarakat Institut Kesehatan Medistra Lubuk Pakam, Direktur Rumah Sakit Grandmed Lubuk Pakam, dan semua pihak yang telah mendukung kegiatan PKM ini yang tidak dapat disebutkan satu per satu.

\section{Daftar Pustaka}

Ana, Z. (2015). Nyeri Konsep \& Penatalaksanaan Dalam Praktik Keperawatan Berbasisi Bukti. Jakarta: Salemba Medika.

Anggara, F.H.D., \& Prayitno, N. (2015). Faktor-Faktor Yang Berhubungan Dengan Tekanan Darah Di Puskesmas Telaga Murni, Cikarang Barat Tahun 2015. Diakses dari https://anzdoc.com/faktorfaktoryang-berhubungan-dengantekanan-darah-di-puske.html.

Haris, S dan Tambunan, T. 2009. Hipertensi pada Sindrom Metabolik. Sari Pediatri, Vol. 11, No. 4, hal. 257-263.

Kemenkes Republik Indonesia. (2015). Profil data kesehatan Indonesia tahun2011.http://www.depkes.g o.id/downloads/profil_data_keseh atan_indonesia_tahun_2011.pdf.

Kowalak,J.P.,Welsh,W. \& Mayer, B. (2016). Buku ajar patofisiologi. Jakarta : EGC.

Muhlisin Abi. (2013). Analisi Pengaruh Faktor Stres terhadap Kekambuhan Penderita Hipertensi di Puskesmas Bendosari Sukoharjo.Prosiding Seminar Ilmiah Nasional Kesehatan, ISSN:2338-2694.

Mutaqqin, A. (2015). Asuhan Keperawatan klien dengan gangguan sistem kardiovaskuler. Jakarta : Salemba Medika. 
Received: 17 June 2021 :: Accepted: 22 June 2021 :: Published: 30 June 2021

Noorhidayah, Yasmina, A., \& Santi, E. (2013). Terapi Kompres Panas Terhadap Penurunan Tingkat. DK Vol.01, 73-80.

Purwanto, B. (2013). Herbal dan Keperawatan Komplementer (Teori, Praktik, Hukum, dalam Asuhan keperawatan). Yogyakarta: Nuha Medika.

Price,S.A., \&Wilson, L. M. (2015). Patofisiologi : konsep klinis proses-proses penyakit. Edisi 6. volume 1. Jakarta : EGC.

Setiadi. (2015). Konsep dan praktik penulisan riset keperawatan. Edisi2. Yogyakarta : Graha Ilmu.

Smeltzer, S. C. Bare, B. G. Hinkle, J. L \& Cheever, K. H. (2010). Brunner \& Suddarth's Textbook Of Medical Surgical Nursing. 11th Edition. Philadelphia: Lippincott Williams \& Wilkins.

Smeltzer, S. D. (2001). Buku Ajar Keperawatan Medikal Bedah Brunner \& Suddart. Jakarta: EGC. Smeltzer. S. C, B. B. (2002). Keperawatan Medikal Bedah Brunner dan Suddarth. Jakarta: EGC.

Smeltzer \& Bare (2013). Buku Ajar Keperawatan Medikal Bedah Brunner Suddarth Edisi 8. Jakarta: EGC.

Snell, R. S. (2016). Anatomi klinis berdasarkan sistem. Jakarta : EGC. 